\title{
Stability of Economic Development of Global Cities: Evaluation and Perspectives
}

\author{
Olha Pyroh \\ Department of Management and \\ International Business \\ Lviv Polytechnic National University \\ Lviv, Ukraine \\ Olha.V.Pyroh@1pnu.ua \\ http://orchid.org/0000-0002-6714-3079
}

\author{
Lyudmyla Katan \\ Department of Finance, Banking and \\ Insurance \\ Dnipro State Agrarian and Economic \\ University \\ Dnipro, Ukraine \\ katanluda@gmail.com \\ http://orchid.org/0000-0002-8466-0609
}

\author{
Vladimir Katan \\ Department of Economic Cybernetics \\ Oles Honchar Dnipro National \\ University \\ Dnipro, Ukraine \\ vlad_aleks@i.ua: \\ http://orchid.org/0000-0001-9167-2619
}

\begin{abstract}
The goal of the article is to explore modern trends and evaluate traits of stable economic development of global cities during the 2000-2017 period. The results of our study reject the hypothesis that innovation activity has a major impact on the economic growth of global cities. Job creation and unemployment reduction are two key factors behind the economic development of global cities, and innovation activity is in third place. By using the integral method we evaluated stability of economic development of 65 global cities during the 2000-2017 period and reached the following conclusions: global cities of Alpha++, Alpha + and Alpha subgroups maintain steady growth; - global cities of Alpha-, Beta +, Beta-, Gamma, Gamma- and High Sufficiency subgroups have unstable and rapid economic growth. Warsaw, Krakow, and Wroclaw are rapidly developing global cities of Central and Eastern Europe with unstable economic development. The rapid economic growth of these cities attracts direct foreign investment, as well as creates an opportunity to reach a new higher level of economic development. However, these three cities overuse existing opportunities for economic development that results in unstable development. A lack of management of economic development can lead to "economic overheat" of these cities.
\end{abstract}

Keywords-global cities, economic development, factors of development, innovation activity, labor factor, stability, integral method, competitiveness, post-industrial society.

\section{INTRODUCTION}

Globalization and rapid technological progress determine the development of the modern world economy. As a result of these processes, global cities, new independent entities of international economic relations, has emerged. Global cities are the driving force for the development of international migration processes, trade, culture, commercial, and political activities. Global cities embody "cities of the future". The new society, social norms, and values along with the new economic activities and new infrastructure are being born in global cities. Moreover, global cities are informational centers, which makes them "global servers that can integrate into global information networks and change them" [1, p. 125].

The following scientists studied global cities and their development in the global environment: S. Sassen [2], M. Castells, J. Friedman, Aaron Rennes [3], P. Taylor, R. Smith [4], and H. Lefebvre [5]. Global city is defined as a "city-conglomerate, through which spread all the economic activity (financial relations, international trade, political power, advanced technology, the organization of global sporting events) in the world" [6, p. 64].

S. Sassen [2], J. Beaverstock, R. Smith [4], and P. Taylor defined the "global city" as special post-industrial production territories, where innovation, collectively with services and finances, is an integral part of the modern restructuring of the global economy, which now is commonly known as globalization.

We have outlined four groups of conceptual approaches to the definition of "global city":

- the economic approach views a global city as one where economic processes are concentrated and managed;

- within the political approach, global cities are represented as national centers that direct international capabilities and influence towards national interests;

- the ideological approach defines a global city as a "center of power" and "a decision-making center that does not necessarily coincide with the capital or city of the nation";

- the logistic approach is based on the concept of the formation of various world financial and investment flows, as well as transport routes that go through a global city.

The main features of global cities include:

- their transformation into centers of governance and policymaking for the world economy (Washington, USA);

- the ability of such cities to act as global financial centers, as centers of specialized services (legal, advertising, etc.) that have a greater impact on economic development than manufacturing, and as leading global commodity markets (London); as well as the place of the entertainment industry, including art, fashion, television, powerful media organizations and internationally-based telecommunications companies (London, New York);

- the ability to attract and house multinational corporations, major national and foreign companies headquartered in its territory (Tokyo has 17 of the 
top 100 corporations, 11 - in New York), as well as house majority of the leading non-governmental and intergovernmental organizations (New York, USA).

Therefore, global cities are urban conglomerates through which all economic activity (financial relations, international trade, political power, the latest technologies, the organization of sports mega-events) in the world is spread. At the same time, the global city is located in a strategically important place on the planet. A city can be considered as a world-class city if it has well-established trade, which is due to more geographical factors than economic and historical development; and as a global city if information technologies are widely used inside of the city and its nearby area.

\section{Methodology of Research}

The purpose of the article is to investigate the current economic trends of the development of global cities, to determine the peculiarities of their development, and to assess the stability of their economic development for the period of 2000-2017.

In order to reach this goal, we set four tasks for research and evaluation of the economic development of global cities:

- $\quad$ study the development of a global city in the context of the history of development, economy, social sphere, infrastructure, culture, etc.;

- $\quad$ analyze the economic development of the global city during the selected period;

- analyze of the hypothesis on the influence of innovative activity of population on GDP and size of the city by using correlation analysis;

- $\quad$ evaluate stability of the economic development of a global city during the studied period.

As an object of research, the economic development of global cities in the global economy was chosen. The subject of the study is the process of socio-economic development of global cities in the context of economic, social, environmental, infrastructure, financial-credit, international, innovation, scientific, educational, and other activities.

After a review of existing studies, we carried out a correlation-regression analysis of the studied indicators, which allowed to determine the relations between them. Five separate indicators that have a significant impact on the stability of the economic development of global cities were recognized:

$X_{1}-$ Gross domestic product (GDP);

$X_{2}$ - Total population;

$X_{3}$ - Geographic and administrative forms;

$X_{4}$ - Unemployment/Employment rate. i.e. Labor market indicators;

$X_{5}$ - Number of patents (PCT patent application) Innovation activity indicator (Patent activity).

The output data was formed by using a statistical database of the global cities from the Organization for Economic Co-operation and Development [7]. The study period is 17 years - 2000-2017, which include years of global crisis - 2008-2009.

In order to assess the stability of the economic development of global cities, an integral method was used [8, p. 89]. The stability of the global city was calculated according to the following equation (1):

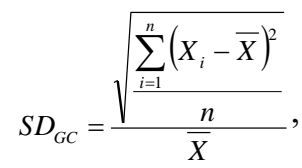

where $X_{i}$ - the studied indicator in the $i$-th period; $\bar{X}-$ average value of the analyzed indicator during the studied period; $i$ - period of study, years $(i=\overline{2000, \ldots, 2017}$ ); $n$ - number of periods.

As a result, $S D_{G C}$ - the integral parameter of stability of economic development of global city was calculated, which can have values in between 0.0 and 0.2. This parameter was classified into four groups by the criteria of mathematical statistics:

- Group 1 includes an indicator of development stability within $0.0 \leq S D_{G C}<0.059$ range, which is characterized by high stability of economic development of global city;

- Group 2 includes an indicator of development stability within $0.06 \leq S D_{G C}<0.09$ range, which is characterized by a medium level of stability of economic development of global city;

- Group 3 includes an indicator of development stability within $0.1 \leq S D_{G C}<0.159$ range, which is characterized by unstable economic development of global city;

- Group 4 includes an indicator of development stability within $0.16 \leq S D_{G C}<0.2$ range and global city is characterized by chaotic economic development, indicating a rapid, disorganized and irregular development.

\section{RESULTS OF RESEARCH}

Below are a few of many classifications, ratings, and indexes of global cities:

- The Global Cities Index (GCI) is calculated by the international company A. T. Kearney and research institute The Chicago Council on Global Affairs. They analyze 125 cities by 27 criteria and arrange them into five groups: human capital (level of education), cultural level (significant sporting events, museums, exhibitions, etc.), political weight (political events, think tanks, embassies), business activity (capital, market dynamics, activity of large companies), information exchange (access to information and the Internet);

- The Global City Competitiveness Index was developed by the British research center The Economist Intelligence Unit. They analyzed 120 the 
most economically developed cities in the world by 31 indicators, such as economic potential, human capital, institutional efficiency, financial maturity, global integration, infrastructure, natural environment, socio-cultural environment;

- The Global Liveability Index (2016) was developed by The Economist Intelligence Unit. This index covers 140 cities and consists of 30 indicators, which are grouped into five groups: stability, healthcare, culture and environment, education, infrastructure.

For our study, the classification Globalization and World Cities (GaWC) [9] was selected. We analyzed 65 cities that represent all the groups of global cities with a share of $21.2 \%$ of their total number:

Group 1 - Alpha - these global cities determine the major trends in the global economy. This group consists of 28 cities $(62.2 \%$ of the total number of global cities in the group):

- Subgroup 1.1 - Alpha++ - the global cities are more integrated into the world system than other cities and make up their own highest level of integration. There are only 2 cities - London (UK) and New York (USA), which represent all $100 \%$ of the global cities in this subgroup;

- Subgroup 1.2 - Alpha+ - other three highly integrated cities accompany London and New York. This subgroup includes the cities representing 37.5\%: Paris (France), Tokyo (Japan), and Sydney (Australia);

- Subgroup 1.3 - Alpha - global cities that connect the largest economic regions and countries with the world economy. These include 9 cities representing 69.2\%: Chicago (USA), Los Angeles (USA), Milan (Italy), Frankfurt (Germany), Toronto (Canada), Madrid (Spain), Mexico City (Mexico), Brussels (Belgium), and Amsterdam (Netherlands);

- Subgroup 1.4 - Alpha- - global cities that are economically important for the global economy. The subgroup includes 14 cities, accounting for 63.6\%: Seoul (South Korea), Vienna (Austria), San Francisco (USA), Washington (USA), Boston (USA), Atlanta (USA), Zurich (Switzerland), Warsaw (Poland), Melbourne (Australia), Barcelona (Spain), Dublin (Ireland), Munich (Germany), Prague (Czech Republic), and Stockholm (Sweden);

Group 2 - Beta - important global cities that contribute to establishing links between their region or country with the world economy. This group included 19 cities $(24.4 \%$ of the total number of global cities in the group):

- Subgroup 2.1 - Beta+ - 10 global cities representing $41.7 \%$ of the global cities in the subgroup: Lisbon (Portugal), Copenhagen (Denmark), Santiago (Chile), Rome (Italy), Dallas (USA), Dusseldorf (Germany), Hamburg (Germany), Berlin (Germany), Athens (Greece), and Budapest (Hungary);

- Subgroup 2.2 - Beta - 4 global cities, which is $22.2 \%$ of the global cities in the subgroup:
Vancouver (Canada), Helsinki (Finland), Stuttgart (Germany), and Geneva (Switzerland);

- $\quad$ Subgroup 2.3 - Beta- - 5 cities representing 13.9\% of global cities in the subgroup: Bratislava (Slovakia), Seattle (USA), Detroit (USA), Denver (USA), and Rotterdam (the Netherlands);

Group 3 - Gamma - global cities that connect smaller regions and countries with the world economy, or important global cities, which main functions do not include the provision of advanced manufacturing services. This group consists of 9 cities $(15.3 \%$ of the total number of global cities in the group):

- Subgroup 3.1 - Gamma+ - 2 cities with a share of $10.53 \%$ of the total number of global cities in the subgroup - Baltimore (USA) and Osaka (Japan);

- Subgroup 3.2 - Gamma - 3 cities representing $16.7 \%$ of global cities in the subgroup - Glasgow (UK), Tallinn (Estonia) and Valencia (Spain);

- Subgroup 3.3 - Gamma- - 4 cities, representing $18.2 \%$ of the total number of global cities in the subgroup - Orlando (USA), Kansas (USA), Krakow (Poland) and Leipzig (Germany);

Group 4 - Delta - cities that are not global cities by definition, but have a sufficient level of services to be independent of global cities. This group included 9 cities ( $7.2 \%$ of the total number of global cities in the group):

- Subgroup 4.1 - High sufficiency - 5 cities with $12.2 \%$ - Strasbourg (France), Wroclaw (Poland), Pittsburgh (USA), Ottawa (Canada) and Dresden (Germany);

- $\quad$ Subgroup 4.2 - Sufficiency - 4 cities, representing $4.8 \%$ of the total number of global cities in the subgroup - Las Vegas (USA), Santa Cruz (USA), Birmingham (USA) and Graz (Austria).

The choice of these global cities for research was due to the availability of initial statistical data for the period 20002017 in the database of the Organization for Economic Cooperation and Development [7].

Structure of the global cities in the study by various criteria (classification groups and subgroups, geographic regions and countries) is as follows:

- by geographical location: most of the global cities are located in Europe (37 cities, 56.9\%) and North America (21 cities, 32.3\%). Whereas the lowest number of global cities are in South and Central America ( 2 cities, $3.1 \%$ ) and the Asia-Pacific region (5 cities, 7.7\%). Such distribution of global cities is explained by the historical development of these territories;

- by country: countries with the highest number of global cities are USA (18 cities), Germany (8 cities), and Canada ( 3 cities). All other countries are represented by 1-2 global city. Such an accumulation of global cities and their strong growth in the USA and Germany is due to the superiority of these 
countries in the development of the world economy at the present time.

Summarizing the results of the study, we identified the following characteristics of the economic development of global cities:

1) Having examined the dynamics of the development of global cities according to the GaWC classifications for 20082016, a steady trend of growth of global cities was discovered. This trend manifests itself in the gradual movement of global cities from weak to more powerful groups and subgroups, as well as in the absence of their chaotic growth. It should be noted that during the research period, the composition of the Alpha++ group did not change: the group retained 2 global cities - London (UK) and New York (USA). However, the composition of other groups das gradually changed;

2) The economic growth of global cities: all global cities are characterized by economic growth but have different paces for the period 2000-2017. Alpha- (30.68\%), Gamma (34.93\%), Gamma- (33.72\%) and High sufficiency (35.64\%) subgroups had the most significant growth during the period. Global cities with the highest levels of economic growth were:

- $\quad$ in Subgroup 1.4 Alpha-: Seoul (South Korea) by $69.3 \%$, Warsaw (Poland) by $68.3 \%$, Prague (Czech Republic) by $52 \%$;

- in Subgroup 2.1 Beta+: Santiago (Chile) by 87.9\%;

- in Subgroup 3.2 Gamma: Tallinn (Estonia) by $68.85 \%$;

- in Subgroup 3.3 Gamma-: Krakow (Poland) by $64.57 \%$;

- $\quad$ in Subgroup 4.1 High sufficiency: Wroclaw (Poland) by $72.2 \%$ over the entire period.

Such a high level of economic growth indicates the active and rapid development of these global cities.

The subgroups Alpha, Beta, and Gamma+ had the lowest levels of economic growth among global cities: $15.08 \%$, $13.04 \%$ and $13.98 \%$, respectively.

Some of the global cities had a decline or no growth in GDP in comparison to the beginning of the studied period:

- Subgroup 2.1 Beta+: Lisbon (Portugal) by $-1.18 \%$, Athens (Greece) by $-1.59 \%$;

- $\quad$ Subgroup 2.2 Beta-: Detroit (USA) down by $8.86 \%$.

3) Economic growth rate: almost all global cities can be characterized by positive growth rates for the period from 2000 to 2017. In 2008-2009 there was a decline in GDP in all global cities, which was the result of the global financial and economic crisis. However, all global cities have regained economic growth in 2010.

The growth rate of group Alpha (Alpha++, Alpha+, Alpha, Alpha-) fluctuated within 10 percentage points (pp) from $104.47 \%$ to $96.96 \%$. This group has the narrowest range with the lowest growth and decline rates among all global cities, which indicates a high level the stability of their development and the ability to counteract the influence of external factors.

The widest range of growth and decline rates belongs to groups Gamma (Gamma, Gamma-) and Delta (High Sufficiency, Sufficiency). During the studied period, a growth rate fluctuated from $107.93 \%$ to $92.73 \%$ with a range over $10 \mathrm{pp}$, which shows the instability of economic development and the noticeable influence of external factors on the global cities.

The results of the study revealed the peculiarity of the economic growth of global cities: the faster growth of GDP the wider the range of economic growth during the period. This feature is typical of Seoul (South Korea / Alpha-) 13.73 pp, Prague (Czech Republic/Alpha-) - 13.3 pp, Tallinn (Estonia / Gamma) - 24.56 pp, Krakow (Poland / Gamma-) - 11.23 pp and Wroclaw (Poland / High sufficiency) - $12.11 \mathrm{pp}$. In addition to the benefits of such economic development, the main threat to global cities is the "overheating" of the city's economy and the strong influence of external factors, which in the future can lead to a sharp decline in economic development and the crisis of the city's economy.

4) GDP per capita: global cities of the Alpha and Beta groups have 1.5 times higher GDP per capita than GDP per capita of that country. Global cities of the Gamma and Delta groups have lower GDP per capita than in the country overall. For example, GDP per capita of New York (Alpha++) exceeds the USA GDP per capita in 1.47 times, San Francisco and Boston (Alpha-) - 1.7 times, Warsaw (Alpha-) - 2 times and Bratislava (Beta-) - 2.2 times.

5) The share of GDP of the global city in GDP of the country: the following relations between the level of economic development, the number of global cities in the country and the input of the global city into the country's GDP were founded: the more economically powerful a country is and the more developing global cities are in it, the lower the contribution of the global city's GDP (up to 10\%) into the GDP of the country by its share.

For example, the United States of America has the highest number of developing global cities in the world, which also have a share in the country's GDP up to 10\%: Los Angeles (Alpha) $-5.72 \%$, San Francisco (Alpha-) - 3.67\%, Chicago (Alpha) $-3.54 \%$ and Washington (Alpha-) $-2.78 \%$. Germany has a similar situation: Munich (Alpha-) $-5.49 \%$ of Germany's GDP, Berlin (Beta+) - 4.91\%, Hamburg (Beta+) $-4.70 \%$, and Frankfurt (Alpha) $-4.26 \%$.

On contrary to previous cities, the less economically developed country is and fewer global cities there are, the bigger share of GDP of a global city (more than 10\%) is in the GDP of the country.

For instance, London (Alpha++) forms $28.39 \%$ of Great Britain's GDP, Seoul (Alpha-) - 46.26\% of South Korea's GDP, Tokyo (Alpha+) - 32.02\% of Japan's GDP, Toronto (Alpha) - $18.91 \%$ of Canada's GDP, Sydney (Alpha+) $19.96 \%$ of Australia's GDP.

Also the largest share of the country's GDP is formed by those global cities which have high growth rate: Tallinn (Gamma) $-60.37 \%$ of Estonia's GDP, Santiago (Beta + ) $48.14 \%$ of Chile's GDP, Budapest (Beta+) $-47.7 \%$ of 
Hungary's GD, and Athens (Beta+) - 44.69\% of Greece's GDP.

At the same time, it does not matter whether this global city is the capital of a country, it is more important what kind of the regional center in terms of high technology services the city is. For instance, the share of New York's GDP (Alpha++) forms $7.73 \%$ of the USA GDP, while New York is not the capital of the USA.

6) Social development of global cities: during the period from 2000 to 20017, the growth rate of the population of global cities was 2-2.5 times lower than the rate of economic growth and within the range of 8.76-17.23\%. Moreover the population of Beta-, Gamma+ groups increased by $4.67 \%$ and $4.14 \%$ respectively, indicating a gradual outflow of population from these global cities.

At the beginning of the study, a hypothesis on the impact of the innovation activity of the population on GDP [10], [11] and the size of the city was proposed. By using correlation analysis, this hypothesis was rejected, since the correlation coefficient $r\left(X_{1}, X_{5}\right)$ between $\operatorname{GDP}\left(X_{l}\right)$ and Patent activity $\left(X_{5}\right)$ is within the $[0,2 ; 0,85)$ range and less than $r\left(X_{1}, X_{4}\right)$ of GDP $\left(X_{l}\right)$ and Labor Market $\left(X_{4}\right)$. The correlation coefficient $(r)$ of GDP $\left(X_{I}\right)$ and Labor Market $\left(X_{4}\right)$ for most global cities of all groups is within [0.85; 0,99], which indicates a high direct correlation between the indicators. Only Tokyo (Japan / Alpha+) and Sydney (Australia / Alpha+) out of 65 global cities have $r\left(X_{1}, X_{5}\right)$ is higher than $r\left(X_{1}, X_{4}\right)$ and is within [0.94; 0.99].

Hence, for the economic development of the global city, the economically active population and a high level of employment are more important than the level of innovation activity. For the economic development of a global city, it is crucial to create jobs, and then to stimulate the innovative activity of enterprises and workers.

The assessment of the stability of the economic development of global cities by classification subgroups was carried out using the integral method for the period 20002017. The evaluation results are presented in Table. 1.

The results of the assessment of the stability of the economic development of global cities indicate that cities in the subgroups Alpha++, Alpha+, and Alpha develop steadily since these global cities are already of high priority for the global economy and have a significant impact on global development. The vast majority of American global cities are found in these groups. According to the ranking of American Cities of the Future 2017/18 [12], "cities of the future" and attractive for foreign investment were called New York and San Francisco. New York is ahead of any other global USA city by economic development. In 2012-2016, 819 foreign direct investment projects were implemented in the metropolis. Direct foreign investment was invested by companies from Western Europe $(68.6 \%$ of total investment), the Asia-Pacific region (14.8\%) and North America (6.7\%).

According to American Cities of the Future 2017/18 [12], Toronto and Vancouver are two Canadian global cities that were called "cities of the future" and are attractive for foreign investments. Toronto attracts $1 / 3$ of all foreign direct investment to Canada. $72 \%$ of the total volume of direct
TABLE I. STABLITY OF ECONOMIC DEVELOIPMENT OF GLOBAL CITIES BY SUBGROUPS FOR THE PERIOD 2000-2017

\begin{tabular}{|c|c|c|c|c|}
\hline \multirow{2}{*}{$\begin{array}{c}\text { Classification } \\
\text { subgroups }\end{array}$} & \multicolumn{4}{|c|}{ Groups of stability of economic development } \\
\hline & $\begin{array}{l}\text { 1 group } \\
0.0 \leq \\
S D_{G C} \\
<0.059 \\
\end{array}$ & $\begin{array}{l}\text { group } \\
0.06 \leq \\
S D_{G C} \\
<0.09 \\
\end{array}$ & $\begin{array}{l}\text { 3 group } \\
0.1 \leq \\
S D_{G C} \\
<0.159 \\
\end{array}$ & $\begin{array}{c}4 \text { group } \\
0.16 \leq \\
S D_{G C} \\
<0.2\end{array}$ \\
\hline Alpha++ & $\begin{array}{l}\text { New York } \\
\text { (USA) }\end{array}$ & $\begin{array}{l}\text { London } \\
\text { (UK) }\end{array}$ & - & - \\
\hline Alpha+ & Tokyo (Japan) & $\begin{array}{c}\text { Paris } \\
\text { (France) } \\
\text { Sydney } \\
\text { (Australia) }\end{array}$ & - & - \\
\hline Alpha & $\begin{array}{c}\text { Chicago } \\
\text { (USA) } \\
\text { Milan (Italy) } \\
\text { Frankfurt } \\
\text { (Germany) } \\
\text { Los Angeles } \\
\text { (USA) }\end{array}$ & $\begin{array}{c}\text { Toronto } \\
\text { (Canada) } \\
\text { Mexico } \\
\text { City } \\
\text { (Mexico) } \\
\text { Amsterdam } \\
\text { (Netherlands) } \\
\text { Brussels } \\
\text { (Belgium) } \\
\end{array}$ & $\begin{array}{l}\text { Madrid } \\
\text { (Spain) }\end{array}$ & - \\
\hline Alpha- & $\begin{array}{c}\text { Vienna } \\
\text { (Austria) } \\
\text { Zurich } \\
\text { (Switzerland) } \\
\text { Boston (USA) } \\
\text { Munich } \\
\text { (Germany) } \\
\text { Atlanta (USA) }\end{array}$ & $\begin{array}{c}\text { San } \\
\text { Francisco } \\
\text { (USA) } \\
\text { Melbourne } \\
\text { (Australia) } \\
\text { Barcelona } \\
\text { (Spain) }\end{array}$ & $\begin{array}{c}\text { Seoul } \\
\text { (South } \\
\text { Korea) } \\
\text { Washington } \\
\text { (USA) } \\
\text { Dublin } \\
\text { (Ireland) } \\
\text { Stockholm } \\
\text { (Sweden) } \\
\text { Prague } \\
\text { (Czech } \\
\text { Republic) } \\
\end{array}$ & $\begin{array}{l}\text { Warsaw } \\
\text { (Poland) }\end{array}$ \\
\hline Beta+ & $\begin{array}{c}\text { Lisbon } \\
\text { (Portugal) } \\
\text { Copenhagen } \\
\text { (Denmark) } \\
\text { Rome (Italy) } \\
\text { Hamburg } \\
\text { (Germany) } \\
\text { Dusseldorf } \\
\text { (Germany) }\end{array}$ & $\begin{array}{c}\text { Berlin } \\
\text { (Germany) }\end{array}$ & $\begin{array}{c}\text { Dallas } \\
\text { (USA) } \\
\text { Athens } \\
\text { (Greece) } \\
\text { Budapest } \\
\text { (Hungary) }\end{array}$ & $\begin{array}{c}\text { Santiago } \\
\text { (Chile) }\end{array}$ \\
\hline Beta & $\begin{array}{c}\text { Stuttgart } \\
\text { (Germany) } \\
\text { Geneva } \\
\text { (Switzerland) }\end{array}$ & $\begin{array}{l}\text { Helsinki } \\
\text { (Finland) }\end{array}$ & $\begin{array}{l}\text { Vancouver } \\
\text { (Canada) }\end{array}$ & - \\
\hline Beta- & - & $\begin{array}{c}\text { Detroit } \\
\text { (USA) } \\
\text { Denver } \\
\text { (USA) } \\
\text { Rotterdam } \\
\text { (Netherlands) }\end{array}$ & $\begin{array}{l}\text { Seattle } \\
\text { (USA) }\end{array}$ & $\begin{array}{l}\text { Bratislava } \\
\text { (Slovakia) }\end{array}$ \\
\hline Gamma+ & $\begin{array}{c}\text { Baltimore } \\
\text { (USA) } \\
\text { Osaka (Japan) }\end{array}$ & - & - & - \\
\hline Gamma & - & $\begin{array}{c}\text { Glasgow } \\
\text { (UK) } \\
\text { Valencia } \\
\text { (Spain) }\end{array}$ & - & $\begin{array}{c}\text { Tallinn } \\
\text { (Estonia) }\end{array}$ \\
\hline Gamma- & $\begin{array}{c}\text { Kansas City } \\
\text { (USA) }\end{array}$ & $\begin{array}{c}\text { Leipzig } \\
\text { (Germany) }\end{array}$ & $\begin{array}{c}\text { Orlando } \\
\text { (USA) }\end{array}$ & $\begin{array}{l}\text { Krakow } \\
\text { (Poland) }\end{array}$ \\
\hline High sufficiency & $\begin{array}{l}\text { Strasbourg } \\
\text { (France) } \\
\text { Ottawa } \\
\text { (Canada) } \\
\end{array}$ & $\begin{array}{c}\text { Dresden } \\
\text { (Germany) }\end{array}$ & $\begin{array}{c}\text { Salt Lake } \\
\text { City (USA) }\end{array}$ & $\begin{array}{l}\text { Wroclaw } \\
\text { (Poland) }\end{array}$ \\
\hline Sufficiency & $\begin{array}{l}\text { Birmingham } \\
\text { (USA) }\end{array}$ & $\begin{array}{c}\text { Graz } \\
\text { (Austria) } \\
\text { New } \\
\text { Orleans } \\
\text { (USA) }\end{array}$ & $\begin{array}{c}\text { Las Vegas } \\
\text { (USA) }\end{array}$ & - \\
\hline
\end{tabular}

Note: compiled and calculated $(*)$ by authors according to the data [7]

foreign investment in Toronto are going into the trade, marketing, and business services sectors. Vancouver, according to the rating [12], leads by the criteria "economic potential" and "doing business" in the category "Big city". In the period from 2012 to 2016, 99 foreign direct investment projects were implemented in the city, almost one-third of them in the software and IT sector. Direct foreign investment in Vancouver software industry came from IT giants: Amazon, Microsoft, and Hewlett-Packard. 
According to fDiIntelligence [13], Dusseldorf (Germany) was classified as a "city of the future" and attractive for foreign investments. Dusseldorf is a multi-industrial city, such as fashion, advertising, biology, law, business consulting, technology, telecommunications, banking, insurance and industry, IT industry. The city houses 9,540 foreign companies from the leading countries: the Netherlands (581 companies), the United States of America (431 companies), the United Kingdom (405 companies), China (385 companies), Switzerland (268 companies), as well as TNCs: WPP, Omnicom, Clifford Chance, Hogan Lovells, Linklaters, White \& Case, Freshfields and others.

The Alpha-, Beta+, Beta-, Gamma, Gamma- and High sufficiency subgroups include those global cities that are characterized by rapid, chaotic economic development with a wide range of economic growth rate which can lead to overheating of the economies of these cities.

The rapidly growing cities, whose development is estimated to be volatile and chaotic, includes 3 Polish cities Warsaw, Krakow and Wroclaw, which were ranked "cities of the future" and attractive to foreign investment, according to the Polish Cities of the Future 2017/18 [14]:

- For Warsaw, business and financial services are two main sectors with active development. As a result of Brexit, Warsaw has begun to compete with such financially giant cities such as Frankfurt and Paris for financial companies that might relocate from the UK, after it leaving the EU. According to Bloomberg, the Polish government is negotiating with 30 companies regarding their potential presence in Poland;

- Krakow was classified as a city-technological center, since one fifth of direct foreign investment was attracted to the software and IT sectors. The main advantages for companies in Krakow are its image as a technology center and the creation of an environment for research (offices and multifunctional buildings for start-ups and new companies, a special economic zone, tax breaks, state aid for investment companies);

- Wroclaw has the highest level of reinvestment among Polish cities. The Swiss company Nestlé expanded its production in the city by investing 44 million US dollars in Purina - PetCare product at the end of 2015. International subsidiary Cadbury and American conglomerate $3 \mathrm{M}$ have expanded Mondelez's production in Wroclaw. The influx of investments in Wroclaw enabled the implementation of various infrastructure improvements: street reconstruction, modernization of public transport, and the construction of a large sports stadium.

Consequently, global Polish cities are actively using existing opportunities for economic development, which leads to their unstable development.

\section{CONCLUSIONS}

By conducting research on economic growth and assessing the stability of the economic development of global cities, we defined the main trends and features of economic growth and development of global cities for the period 2000-
2017. The results of our study reject the hypothesis that innovation activity has a major impact on the economic growth of global cities. Job creation and unemployment reduction are two key factors behind the economic development of global cities, and innovation activity is in third place. Global cities of Alpha++, Alphat and Alpha subgroups maintain steady growth. Global cities of Alpha-, Beta+, Beta-, Gamma, Gamma- and High Sufficiency subgroups have unstable and rapid economic growth, that attracts direct foreign investment, as well as creates an opportunity to reach a new higher level of economic development. However, abuse of these factors and lack of management will result in "economic overheat" of these cities.

\section{REFERENCES}

[1] O.K. Chaplyhin, and O.Ye. Suk, "Global city in the structure of a post-industrial society", in VI International scientific-theoretical Internet-conf. City. Culture. Civilization, Kharkov, 2016, pp. 124-128.

[2] S. Sassen, "The Global City: Enabling Economic Intermediation and Bearing Its Costs". City \& Community, vol. 15:2, pp. 97-108, 2016.

[3] A.M. Renn, "What is a Global City? New Geography". [Online]. Available: http://www.newgeography.com/content/003292-what-is-aglobal-city.

[4] R.G. Smith, "Beyond the Global City Concept and the Myth of "Command and Control". International Journal of Urban and Regional Research, vol. 38 (1), pp. 98-115, 2014.

[5] H. Lefebvre, The urban revolution. Minneapolis, USA: University of Minnesota Press, 2014.

[6] O. Pyroh, and Ya. Maksymchuk, "Conceptual foundations of global cities: scientific approaches to defining the essence". Visnyk of Dnipro University. Ser. World Economy and International Economic Relations, vol. 10 / 2, no. 22, pp. 64-71, 2017.

[7] Data base of Metropolitan areas during 2000-2017. Organisation for Economic Co-operation and Development. [Online]. Available: https://stats.oecd.org/Index.aspx?DataSetCode=CITIES\#. Accessed on: July 10, 2019.

[8] O. Kyzmin, and O. Pyroh, "The integral method to estimate the stable development of national economy under the conditions of postindustrial society". Actual Problems of Economics, vol. 142, Is. 4 , pp. $\quad$ 88-102, $2013 . \quad$ [Online]. Available:: https://www.scopus.com/record/display.uri?eid=2-s2.084929998884\&origin $=$ resultslist\&sort $=$ plf-

$\underline{\mathrm{f} \& \mathrm{src}=\mathrm{s} \& \mathrm{sid}=2857 \mathrm{cb} 6818 \mathrm{c} 6231 \mathrm{~d} 3 \mathrm{~b} 86 \mathrm{c} 51 \mathrm{~b} 78 \mathrm{~b} 7496 \mathrm{f} \& \mathrm{sot}=\mathrm{autdocs} \& \mathrm{~s}}$ $\mathrm{dt}=$ autdocs $\& \mathrm{sl}=18 \& \mathrm{~s}=\mathrm{AU}-$

ID $2856658681200 \% 29 \&$ relpos $=0 \&$ citeCnt $=0 \&$ searchTerm $=$. Accessed on: July 17, 2019.

[9] Globalisation and World Cities (GaWC). The World According to GaWC. 2018. [Online]. Available: http://www.lboro.ac.uk/gawc/gawcworlds.html Accessed on: July 17, 2019.

[10] Yu.I. Parcshyn, Strategy of ensuring stable economic development of national economy: theory, methodology and practice. Dnipro, Ukraine: Alfred Nobel University, 2016.

[11] A.Yu. Vasyna, Structural reform of national economy: methodological and intuitional aspects. Ternopil, Ukriane: Econ. dymka TNEU, 2017.

[12] American Cities of the Future 2017/18. [Online]. Available: http://www.fdiintelligence.com/Locations/Americas/fDi-AmericanCities-of-the-Future-2017-18-FDI-Strategy-winners. Accessed on: July 15, 2019

[13] Digital Düsseldorf: Industrial hub adds ICT success to the mix. [Online]. Available: http://www.fdiintelligence.com/SpecialReports/Duesseldorf-s-subtle-charm-wins-over-investors-andworkers-alike. Accessed on: July 14, 2019.

[14] Polish Cities of the Future 2017/18. [Online]. Available: http://www.fdiintelligence.com/Locations/Europe/Poland/fDi-sPolish-Cities-of-the-Future-2017-18-FDI-strategy-winners. Accessed on: July 17, 2019. 